\title{
"Parcerias" com a cana-de-açúcar: tensões e contradições no desenvolvimento das experiências de assentamentos rurais em São Paulo
}

\author{
VERA LUCIA SILUEIRA BOTTA FERRANTE" \\ LÚS ANTONIO BARONE*
}

\section{Resumo}

A controversa presença da cana nos assentamentos rurais nos últimos anos exige uma cuidadosa reflexão sobre sua interferência no modo de vida dos assentados e na relação dos assentamentos com a dinâmica do desenvolvimento regional. A presença da cana-de-açúcar nos assentamentos tem causado conflitos internos e debates não consensuais sobre o passado/presente/futuro dessas experiências. A análise da parceria com as agroindústrias é atravessada, do nosso ponto de vista, pela noção de trama de tensões, exigindo que sejam submetidas ao crivo analítico as desigualdades constitutivas desta polêmica integração dos assentados às usinas de açúcar e álcool, assim como as consequências socioeconômicas e ambientais da problemática transformação dos assentamentos rurais em celeiros da cana. No âmbito desse artigo, serão considerados como objetos da investigação os assentamentos das regiões de Araraquara e do Pontal do Paranapanema e analisadas perspectivas de outro modelo de desenvolvimento.

Palavras-chave: Assentamentos rurais. Reforma agrária. Expansão da cana. Impactos socioeconômicos e ambientais.

\footnotetext{
* Pesquisadora do CNPq, coordenadora do Mestrado em Desenvolvimento Regional e Meio Ambiente do Centro Universitário de Araraquara (Uniara). mestrado@uniara.com.br

** Professor-Doutor do Departamento de Planejamento da FCT/UNESP - Presidente Prudente (SP). laborone@uol.com.br
} 
Introdução: A perspectiva de análise frente a um itinerário de questões polêmicas

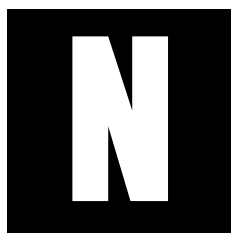

o Brasil do Século XXI, onde a maioria da população habita áreas urbanas, o assentamento de centenas de milhares de famílias de trabalhadores - boa parte delas composta de ex-assalariados rurais - em projetos de reforma agrária suscita questões sobre as dificuldades de ressocialização desse segmento social. A luta pela terra e a consequente política de assentamentos rurais desenvolvida no Estado de São Paulo nos últimos vinte anos têm colocado, tanto para pesquisadores quanto para gestores públicos e população assentada, questões e desafios no desenvolvimento destas experiências de democratização do acesso à terra na unidade mais modernizada da federação.

A situação de assentamento significa uma mudança de perspectiva para esses trabalhadores. As estratégias de gestão do trabalho e do território, desenvolvidas por esse segmento - sempre em tensão (às vezes em conflito aberto) com outros agentes que se movimentam no interior do campo de forças formado pelo desenvolvimento da política de assentamentos rurais -, se somam com outras dimensões da vida social, compondo um singular modo de vida.

A partir de uma pesquisa qualitativa e longitudinal desenvolvida pelo Nupedor ${ }^{1}$, acompanhando a trajetória de áreas reformadas e das famílias aí instaladas, buscamos refletir sobre as experiências passadas e presentes desses trabalhadores com relação às dificuldades de organiza-

1 O Núcleo de Pesquisa e Documentação Rural (Nupedor), formado em 1988, reúne pesquisadores e estudantes da área de Ciências Sociais da FCL/UNESP - Araraquara- e do Centro Universitário de Araraquara (Uniara). 
ção da produção e de integração econômica. O objetivo dessas análises é compreender os processos e os bloqueios referentes à integração desses Projetos de Assentamentos na economia regional, bem como os avanços e recuos dessa categoria nova - os assentados - em sua busca por reconhecimento e cidadania.

O trabalho ora apresentado busca avaliar um aspecto bastante polêmico desse processo, qual seja, a controversa situação de integração produtiva dos assentamentos de reforma agrária ao sistema agroindustrial sucroalcooleiro, a partir de estudos realizados nas duas regiões do Estado onde esta situação é verificada: Araraquara (que inclui este município e os limítrofes) e Pontal do Paranapanema (mais especificamente no município de Teodoro Sampaio). A presença constatada da cultura agroindustrial da cana-de-açúcar nos assentamentos rurais expõe o futuro destas experiências de Reforma Agrária a contradições de natureza diversa, o que exige um olhar atento e crítico sobre essa trajetória.

Não se trata, aqui, de avaliar a expansão da cana em si mesma, mas de analisar as consequências do sistema de poderes e de controles a ela ligados. Daí a opção de discuti-la a partir da noção de trama de tensões. As trajetórias, tanto dos trabalhadores, quanto da expansão da cana-deaçúcar no interior dos assentamentos, ganham uma maior inteligibilidade a partir da leitura dessa trama, da qual são partes constitutivas. Os assentamentos, experiências inovadoras na gestão econômica do território, acabam por expressar tensões que são reveladoras das contradições e possibilidades da chamada agricultura familiar frente ao poder do capital agropecuário e agroindustrial, no âmbito do desenvolvimento social no campo paulista. A introdução e o crescimento da cana criam pontos de inflexão neste processo.

A trama, nesse caso, é a constituída pelas relações travadas entre distintos atores, sendo destacados, nesse estudo, os próprios assentados e 
os diferentes mediadores tanto das políticas públicas como das possíveis alternativas econômicas. O confronto desses atores nos espaços sociais de disputa e constituição das políticas públicas é gerador dessa trama de tensões, opondo interesses e racionalidades diversas, mediante distintos projetos, compromissos e estratégias. Assim, a inserção sempre problemática dos assentamentos nos distintos contextos regionais a partir da expansão da cana cria uma nova trama de relações sociais, revelando tensões entre as práticas e as racionalidades dos diferentes agentes (assentados, técnicos, agentes políticos e outros mediadores) no interior do campo de forças sociais que disputam os destinos da reforma agrária, dimensionado a partir da escala local/microrregional.

Resulta dessa reflexão sociológica a percepção da força desses agentes sociais - os assentados -, por vezes relegados ao preconceito (teórico e político), lutadores por um pedaço de chão. Inseridos num contexto que lhes é, muitas vezes, hostil, esses trabalhadores rurais, a partir de suas perspectivas e consciências, acabam por ser os protagonistas dos processos nos quais estão inseridos.

Os assentados aparecem como sujeitos muitas vezes em posição de subalternidade, porém com presença ativa e desenvolvendo estratégias, mais ou menos coerentes, de possíveis projetos políticos de fortalecimento da agricultura familiar via assentamentos. Outras vezes, parecem tão somente submergir num sistema de controles e de poderes que os aniquila. Essa ambiguidade está bastante presente nas distintas maneiras pelas quais usinas, órgãos técnicos, agências de mediação e trabalhadores assentados se posicionam na discussão e no encaminhamento das ações no tocante a plantar ou não plantar cana para as agroindústrias.

Falar nas tensões sociais constituintes do espaço social dos assentamentos significa abordar essa realidade, destacando as resistências e acomodações que são empiricamente verificadas na construção das relações 
entre os distintos atores sociais presentes no contexto socioeconômico e político estudado. Dessa forma, os condicionantes mais estruturais se fazem sentir nesta abordagem, mas não de maneira a serem privilegiados como objeto de análise. Em questão está a movimentação dos atores neste cenário, tendo sempre os trabalhadores assentados como ponto de partida dessa trama.

Assim, a inserção dos assentamentos nos contextos regionais pode revelar-se mais ou menos problemática, mas sempre se dará mediante o fazer-se de uma tessitura social cuja trama revela tensões entre as práticas e as racionalidades desses distintos atores. A investigação e a avaliação das trajetórias das experiências de assentamentos rurais em São Paulo têm se dedicado a discutir suas relações com o entorno local/regional e suas perspectivas e bloqueios a um desenvolvimento que contemple as expectativas dos trabalhadores assentados. ${ }^{2}$ Nessa empreitada já realizada (mas sempre demandante de atualizações e ampliações), discute-se criticamente a noção de "impactos" do processo de implantação dos assentamentos rurais. ${ }^{3}$ Tal noção parece adequada para uma compreensão dos processos locais e regionais de amplo espectro. No entanto, conforme afirmam alguns dos próprios pesquisadores que tomamos como referência,

esses processos de transformação [causados pelos assentamentos rurais], para os quais muitas vezes o termo "impacto" pode ser excessivo (uma vez que ele tende a chamar a

\footnotetext{
2 As reflexões sobre essa temática estão propostas no Projeto de Pesquisa (Auxílio Integrado $\mathrm{CNPq}$ ) "Assentamentos rurais e desenvolvimento: tensões, bloqueios e perspectivas (uma análise comparativa em duas regióes do estado de São Paulo)" e se materializaram em trabalhos por nós publicados (Cf. FERRANTE, V. L. S. B. e BARONE, L.A. "Assentamentos Rurais e Desenvolvimento: Tensões, bloqueios e perspectivas" texto apresentado no Seminário Internacional sobre Reforma Agrária e Desenvolvimento - FAO/INCRA, Porto Alegre, março/2006 dos mesmos autores: "Reforma Agrária e Desenvolvimento como liberdade: uma nova visão sobre os assentamentos rurais do Estado de São Paulo" - Revista Retratos de Assentamentos. Nupedor/ Uniara, Araraquara/SP, no. 10, 2006).
}

3 Cf. LEITE et. al., 2004; MEDEIROS E LEITE, 2004. 
atenção para o mais visível e espetacular), muitas vezes têm caráter molecular [grifo nosso] e só se potencializam ao longo do tempo... (LEITE et. al., 2004, pp. 20-21).

Propõe-se, neste trabalho, um aprofundamento da análise em direção justamente dessas relações sociais moleculares, que constroem a dinâmica dos contextos sociopolíticos nos quais os assentados estão inseridos. Neste sentido, discutir a tessitura de uma trama de tensões sociais, a partir da prática desses agentes, cuja racionalidade social transita numa relação complexa entre resistência e acomodação, parece ser mais adequado para a compreensão desses processos. Mesmo que condicionadas por dinâmicas que lhes são impostas de fora - e este é o caso da cultura da cana-de-açúcar agroindustrial - tais práticas constituem a história viva de trabalhadores que, estando numa posição estrutural de subalternidade social, organizam estratégias - individuais ou coletivas - cuja consecução, senão amplamente transformadora das relações sociais, revela aspectos inovadores e singularmente determinantes da realidade da qual participam como sujeitos.

Assumimos a busca, proposta por José de Souza Martins, por uma sociologia rural que é a sociologia de um modo de ser e um modo de viver mediados por uma maneira singular de inserção nos processos sociais e no processo histórico (MARTINS, 2002, p. 220). O modo de vida em questão é o constituído pelos assentados em sua busca por sustentabilidade num campo de disputas definido pelo jogo das forças sociais presentes no âmbito local/regional. Os assentados são sim os artífices desse modo de vida, mas o fazem sempre numa situação relacional. Os confrontos com as demais forças sociais (capital regional, agentes oficiais dos órgãos estatais responsáveis pela reforma agrária e agentes do poder público municipal) podem ter, na relação com a cana, cenário privilegiado de observação.

Na região de Araraquara, as formas de cessão das terras dos assentamentos para plantio da cana vão desde uma controvertida "parceria" 
- com anuência oficial do ITESP ${ }^{4}$ - até uma estratégia de organização associativa que se põe em confronto com as determinações do INCRA no tocante a esse tipo de atividade. Grupos prós e contra a introdução da cultura agroindustrial se conflitam, às vezes de forma agressiva. A orientação dos órgãos oficiais, que se tornará flagrantemente divergente ao longo dos anos em que esse processo se desenvolve, denota a falta de uma perspectiva comum em termos de política pública para a reforma agrária e torna mais complexa essa realidade.

Na região do Pontal do Paranapanema (especificamente nos assentamentos do município de Teodoro Sampaio), a opção pelo plantio de cana para as agroindústrias tem como estimulador uma destilaria que se vale, num primeiro caso, de uma "experiência piloto" (que extrapola o oficialmente aprovado pelo INCRA) no assentamento Água Sumida. Num momento posterior, verifica-se a introdução da cultura canavieira para fornecimento à mesma usina em projetos de assentamentos que Ihe são vizinhos, desta vez, mediante a mesma instrução oficial do ITESP que autoriza as tais "parcerias". No entanto, a alternativa encontrada para a implantação da cana neste caso coloca o assentado - autoidentificado como "fornecedor" - numa situação de extremo risco, sobretudo ao endividamento bancário a que este se submete na implantação do canavial. Se em Teodoro Sampaio a presença da usina no interior do assentamento surge com um alto grau de consenso, sobretudo pela hegemonia territorial que a mesma exerce naquele quadrante do município, nos P. A.s. de Araraquara essa presença (hegemônica em toda a região) é extremamente polêmica.

4 A Fundação Instituto de Terras do Estado de São Paulo "José Gomes da Silva" (neste texto sempre referida como ITESP) é o órgão estadual implementador da política agrária em São Paulo, com notável atuação na instalação de Projetos de Assentamentos em áreas públicas estaduais e terras devolutas. Para uma maior reflexão sobre a atuação dessa agência cf. BARONE, L. A. "Assistência técnica aos assentamentos de reforma agrária: da política reativa ao vazio de projeto - o caso do Estado de São Paulo". Retratos de Assentamentos. № 08, Araraquara: FCL/ UNESP, 2000. 
As alternativas que envolvem a aceitação ou a recusa em plantar cana para usinas têm que ser compreendidas como parte das relações complexas que envolvem os assentados, as instâncias do poder local, a economia regional e as agências de mediação. Este conjunto, no entanto, tem que ser pensado de uma perspectiva político-social integradora, não unicamente por uma determinação econômica. Controvérsias é que não faltam na discussão dessa questão, que entra necessariamente na agenda das reflexões sobre o presente/futuro dos assentamentos rurais, os quais têm como referência, neste artigo, duas regiões do Estado de São Paulo, diferenciadas em suas relações e em sua dinâmica.

\section{Fragmentos da Caracterização dos Assentamentos}

No território das agroindústrias

Produto de diferentes políticas públicas gestadas ao longo dos últimos vinte anos, a região de Araraquara (região central do Estado de São Paulo) conta com três projetos de assentamentos rurais, sendo dois deles de responsabilidade do ITESP (Monte Alegre e Horto Bueno de Andrade) e um do INCRA (Bela Vista do Chibarro).

Os primeiros núcleos de assentamentos (Monte Alegre I, II, III e IV) foram instalados pelo ITESP nos anos de 1985 e 1986, ainda na gestão do governador Franco Montoro (1983-1986), tendo sua instalação se completado quase dez anos depois. Hoje o projeto de assentamento Monte Alegre conta com seis núcleos, perfazendo um total de 416 lotes agrícolas e, segundo o ITESP, de 418 famílias que ali residem. A área da Fazenda Monte Alegre era, originalmente, pertencente à FEPASA (Ferrovias Paulistas S.A.), estando sob gestão da CODASP (Companhia de Desenvolvimento Agrícola de São Paulo) quando os assentamentos foram conquistados. 
No mesmo período em que o ITESP instalou um dos núcleos mais recentes do projeto de assentamento Monte Alegre - o de número VI, ainda na primeira gestão Mário Covas (1995-1998) - também assentou 31 famílias no Horto de Bueno de Andrada, área também anteriormente pertencente à CODASP e localizada no distrito araraquarense de Bueno de Andrada (que dá nome ao Horto). As dimensões deste projeto de assentamento, além da origem comum da mobilização das famílias ali assentadas e das que foram para o núcleo VI da Monte Alegre, fazem com que o horto de Bueno seja considerado um apêndice do grande projeto de assentamento Monte Alegre.

Além desses núcleos do ITESP, existe um projeto de assentamento promovido pelo governo federal (INCRA) no município de Araraquara: o projeto de assentamento Bela Vista do Chibarro, com 176 lotes agrícolas e (estimadamente) o mesmo número de famílias. O projeto de assentamento Bela Vista se encontra em terras anteriormente pertencentes a uma usina de açúcar (Usina Tamoio), cuja desapropriação data de 1989. A mobilização que levou à instalação deste P.A. acaba sendo emblemática da luta dos trabalhadores rurais nas terras dos canaviais (Ferrante, 1992.a).

Especificamente neste P.A., a observação das formas e da execução da assistência técnica revela, ao longo dos anos, uma relação de estranhamento na esfera das competências e um certo descompasso entre o órgão promotor e o órgão gestor do assentamento (INCRA e ITESP, respectivamente), situação que leva, não poucas vezes, a conflitos entre técnicos e entre técnicos e assentados. A tensão entre dois corpos técnicos, muitas vezes sujeitos às injunções da configuração política de cada esfera de governo, torna a ação conjunta desses órgãos sempre difícil (Barone, 2000). Mais recentemente (2005), o ITESP deixa de prestar assistência técnica na Bela Vista, sendo este serviço assumido pelo INCRA - o que será, também, ingrediente da polêmica envolvendo o cultivo da cana nesse local. 
A trajetória dessas experiências de assentamentos não se diferencia muito das demais, sobretudo no Estado de São Paulo, no tocante à ação dos órgãos públicos responsáveis pelos projetos. A falta de planejamento, a desorganização de um cronograma racional de investimentos e o esvaziamento cíclico da estrutura de assistência técnica (Ferrante e Barone, 1997/1998) acabam por prejudicar em muito o desenvolvimento econômico dos produtores assentados. Conflitos entre assentados ligados a distintas direções políticas, expressos em protestos contra os órgãos técnicos, e conflitos que tiveram interferência nas experiências frustradas de cooperativas e de associações, reavivados por muitas disputas internas, fazem parte desta trajetória.

Em comparação com inúmeros outros projetos, tanto sob responsabilidade do governo estadual quanto do governo federal, a característica mais marcante desses assentamentos é justamente sua inserção territorial numa região de agricultura modernizada, praticamente monopolizada pelas culturas da cana-de-açúcar e de citros. A maior parte das terras agricultáveis da região está cultivada com cana - cuja extensão chega, no município de Araraquara, a cerca de 32 mil hectares e cuja cadeia de produção constitui o maior complexo agroindustrial da região.

Leve-se em conta que, em função mesmo desse entorno socioeconômico, a maioria das famílias assentadas na região tem uma trajetória recente de trabalho imediatamente ligada a essa economia agroindustrial. Perto de $70 \%$ dos assentados no projeto de assentamento Monte Alegre (especialmente dos núcleos II e IV) foram proletários rurais nas culturas de cana e de laranja. No projeto Bela Vista do Chibarro este índice está em torno de 50\%, mesmo que a luta pelo assentamento tenha sido iniciada pelos ex-trabalhadores da usina falida. Ainda hoje, tanto a colheita de laranja como a de cana são formas de assalariamento temporário às quais os assentados recorrem. 
A inserção de trabalhadores boias-frias no movimento de demanda pela terra marcou a constituição dos assentamentos na região. A possibilidade da terra constituir-se em um dos eixos de luta dos boias-frias, categoria que tem, no seu interior, segmentos que não tiveram uma relação direta de apropriação com a terra, criou impasses e exigiu remodelagens de interpretações do processo de modernização/expropriação e proletarização rural (Ferrante, 1992b). Esta origem e a trajetória histórica da população hoje assentada, bem como a de seu principal mediador político (o Movimento Sindical dos Assalariados Rurais), repõem resistências e acomodações específicas frente à integração dos assentados no sistema produtivo sucroalcooleiro, que se relacionam com o tempo anterior, de assalariamento.

Os dilemas da inserção regional desses projetos de assentamento não se referem apenas à trajetória das famílias - um retrato das contradições dessa modernização agrícola - ou à participação no mercado que esses produtores assentados têm ou almejam ter. Desde a sua instalação, o conflito com forças políticas representativas do complexo agroindustrial da cana se fez presente, pautando em muito a discussão sobre os projetos de desenvolvimento dessas experiências de reforma agrária - o que será visto adiante.

\section{Nas terras do "boi gordo"}

Na região conhecida como Pontal do Paranapanema (extremo Oeste paulista), a questão fundiária tem sido - ao longo de décadas - o ponto fulcral definidor das políticas públicas e ingrediente básico das tensões sociais envolvendo o estado e diferentes classes sociais. A região é, portanto, de importância ímpar quando se aborda a temática da reforma agrária no Estado de São Paulo. Com uma ocupação que data do final do século XIX, o Pontal do Paranapanema revela, em seu histórico fundiário, o mais conhecido caso de grilagem de terras do país (Leite, 1999). 
Centenas de ocupações, milhares de trabalhadores mobilizados e acampados, dezenas de ações judiciais discriminatórias promovidas pelo Estado no sentido de identificar e arrecadar as terras devolutas irregularmente ocupadas: esse é o contexto sociopolítico do Pontal do Paranapanema, hoje a região do Estado de São Paulo com o maior número de assentamentos e de famílias assentadas. Nesse cenário, o incremento da política de assentamentos na região aconteceu, sobretudo, na primeira gestão do governador Mário Covas (1995-1998), como resultado de intensas negociações para arrecadação de áreas e o assentamento de milhares de famílias. Dada a importância da região do Pontal do Paranapanema com relação ao número de assentamentos (são 103 Projetos de Assentamentos já instalados, com aproximadamente 5,5 mil famílias assentadas), essa área do Estado tem mostrado uma dinâmica extremamente rica no que tange a essa questão.

Especificamente com relação ao município de Teodoro Sampaio, localizado no coração do Pontal, entre os rios Paraná e Paranapanema, a luta pela terra e a política de assentamentos datam de antes do período mais acentuado de iniciativa estatal (década de 1990, quando também ocorre a estruturação do MST na região), com a presença de acampamentos e "posses" em algumas glebas. Como protagonistas dessas lutas, registradas pelo menos desde os anos 1960 (Antonio, 1990), estão distintas categorias de trabalhadores: arrendatários, posseiros, boias-frias e ex-barregeiros, moradores nesta região do Estado ou no Norte do Paraná.

Um dos segmentos expropriados, talvez o primeiro, que se mobilizou na luta pela terra foi o dos arrendatários. A evolução da questão agrária na região sempre opôs supostos proprietários-fazendeiros e trabalhadores rurais arrendatários, dedicados especialmente à cotonicultura nos anos 1950-60. No entanto, sua situação na terra sempre foi instável, dada a própria natureza da relação de produção. A partir dos anos 1960, intensifica-se a implantação da pecuária de corte, pari passu à sistemática 
expulsão dos arrendatários das terras então destinadas à criação de gado. Nos anos 1970 e 1980, tem-se notícias de casos de lutas pela permanência na terra, encetadas por arrendatários. Algumas dessas lutas chegaram à década de 1990, com acampamentos e ocupações na forma de posse, o que levou a que parte desses trabalhadores fosse beneficiadas pela política de assentamentos realizada no período recente - inclusive no município de Teodoro Sampaio ${ }^{5}$.

O fim do ciclo algodoeiro, que se desenrola durante os anos 1970 e 80, gerou um contingente de boias-frias desempregados, anos mais tarde mobilizados por um pedaço de chão nesta conflagrada região. No caso específico dos assentamentos próximos à Destilaria Alcídia, a pesquisa registrou, também, a presença de ex-trabalhadores rurais da própria empresa sucroalcooleira. Esta, de fato, experimentou dificuldades no final da década de 1980, devido às alterações na política oficial com relação à produção de álcool combustível. Alguns desses ex-trabalhadores da Alcídia, hoje assentados, se gabam, inclusive, das boas relações com a empresa - algo que tem favorecido práticas clientelistas que a usina desenvolve nesses P.A.s.

O terceiro mais importante contingente de sem-terras é o formado pelos ex-barrageiros. Nos anos 1980, tanto a conclusão quanto a drástica diminuição no ritmo das obras das barragens (como no caso da Usina Hidrelétrica "Sérgio Mota", em Rosana, cuja conclusão se arrastou por décadas) geraram um grande desemprego junto aos operários não qualificados que, a partir dos anos 1960, se deslocaram para a região em busca de trabalho nos canteiros de obra nas margens dos rios Paraná e Paranapanema. A mais evidente mobilização desse contingente levou a instalação do assentamento Gleba XV de Novembro, na primeira metade dos anos

5 Registra-se, também, que alguns dos atuais movimentos de luta pela terra na região têm como base o segmento dos arrendatários - caso da Associação Brasileiros Unidos Querendo Terra (ABUQT), com forte atuação nos municípios de Presidente Venceslau e Presidente Epitácio. 
1980 (Fernandes, 1996; Antonio, 1990), maior área de assentamento no Pontal do Paranapanema, localizada entre os municípios de Rosana e Euclides da Cunha Paulista (vizinhos a Teodoro Sampaio).

\section{O modo de vida dos assentamentos e a "parceria" com as agroindústrias}

Dados recentes da Fundação ITESP (Quadro 1) revelam que, em 2008, mais de 350 assentados em projetos da jurisdição do governo estadual, distribuídos pelas regiões Nordeste e extremo Oeste do Estado, têm contratos para fornecimento de cana a diferentes usinas. ${ }^{6}$ Essa distribuição geográfica apresenta situações distintas na constituição das tramas sociais que suportam essa relação.

Indicadores do IEA/SEADE (2005) mostram que os municípios que detêm $70 \%$ de produção com cana no Estado de São Paulo têm, também, os mais baixos índices paulistas de responsabilidade social. Em outros termos, dados apologéticos da cana como vanguarda na produção de renda contrastam com outros (PNAD, 2004) que mostram um agravamento das condições sociais gerais nos municípios com predomínio da cana na sua área agrícola.

6 Estão excluídos deste montante os assentados em projetos de responsabilidade do governo federal, como os aqui citados P.A.s Bela Vista do Chibarro (Araraquara) e Água Sumida (Teodoro Sampaio). 
Quadro 1 - Distribuição dos assentamentos geridos pelo ITESP que implantaram cana- de-açúcar para fornecimento a agroindústrias. ${ }^{7}$

\begin{tabular}{|c|c|c|c|}
\hline $\begin{array}{l}\text { Grupo Técnico } \\
\text { de Campo }\end{array}$ & Agroindústria & Projeto de Assentamento & № de assentados \\
\hline Araraquara & $\begin{array}{l}\text { Usina Santa Luiza - Motuca } \\
\text { Usina Maringá - Araraquara e } \\
\text { Usina São Martinho - Pradó- } \\
\text { polis em processo de oficiali- } \\
\text { zação da parceria }\end{array}$ & $\begin{array}{l}\text { Monte Alegre } \\
\text { Bueno de Andrade } \\
\text { Silvania } \\
\text { Guarany }\end{array}$ & $\begin{array}{c}212 \\
\text { (total de contratos } \\
\text { com a Usina Sta. } \\
\text { Luiza) }\end{array}$ \\
\hline Teodoro Sampaio & Destilaria Alcídia S/A & $\begin{array}{l}\text { Santa Zélia } \\
\text { Sta. T. da Alcídia } \\
\text { Alcídia da Gata } \\
\text { Sta. Cruz da Alcídia }\end{array}$ & $\begin{array}{c}18 \\
6 \\
4 \\
3\end{array}$ \\
\hline Rosana & Destilaria Alcídia S/A & Gleba XV de Novembro & 38 \\
\hline \multirow[t]{2}{*}{ Bebedouro } & $\begin{array}{l}\text { Usina Andrade Açúcar e } \\
\text { Álcool S/A }\end{array}$ & Ibitiúva & 24 \\
\hline & Usina Viralcool S/A & Reage Brasil & 46 \\
\hline
\end{tabular}

Fonte: Fundação ITESP, 2008.

Diante desta expansão, cabe uma primeira reflexão: os assentamentos entraram nessa proposta de instalação/ampliação dos canaviais como atores coadjuvantes. Essa atividade é consequência inevitável do esvaziamento e da falta de continuidade das políticas públicas dirigidas a assentamentos? É efeito da política de cercamento utilizada pelas usinas? É uma estratégia de permanência na terra ou uma manifestação de desobediência face às diretrizes confusas dos órgãos gestores para a política de assentamentos? O quanto esta opção altera o modo de vida desses agricultores assentados?

7 Neste artigo, não serão considerados para análise os assentamentos sob jurisdição dos Grupos Técnicos de Campo (ITESP) de Bebedouro e Rosana, assim como os P.A.s Santa Zélia e Santa Cruz da Alcídia (GTC de Teodoro Sampaio), nos quais a implantação da cana é mais recente. 
Poderíamos associar a complexa transformação dos assentamentos rurais em celeiros de cana à possível falência das experiências de reforma agrária, já que a expansão de cana sugere a reprodução da monotonia da paisagem das monoculturas e das degradadas condições de trabalho a que são submetidos os cortadores de cana, movimento que se põe na contramão das perspectivas de autonomia sugeridas pelas políticas de assentamentos. Se tomarmos a relação dos assentamentos com o desenvolvimento pautada por tensões, que se expressam no modo de vida e na maneira de inserção dos assentamentos nos contextos regionais, como interpretar a expansão da cana nesses espaços? Como ficam as contradições e possibilidades de um tipo de agricultura familiar frente aos constrangimentos estruturais das economias regionais e do entorno sociopolítico? A progressiva presença da cana nos assentamentos seria demonstração do predomínio de ações de acomodação dos assentados face ao ideário de integração econômica aos sistemas produtivos regionais?

Um olhar sobre a trajetória dessas experiências de assentamentos nos mostra a possível construção de um novo modo de vida, que envolve um conjunto de relações, desde as de vizinhança e com a comunidade inclusiva até as com o poder local e com a agricultura regional (sendo que, no caso do Pontal, tais relações esboçam, inclusive, um projeto de desenvolvimento regional via assentamentos). Códigos tradicionais, racionalidades, o vai e vem de formas associativas, a reorganização do espaço produtivo/reprodutivo, os rearranjos em busca da cooperação podem ser observados neste processo. Do mesmo modo, expressões de conflitos, de diferenças, muitas vezes atravessadas por mecanismos de poder, nos quais o clientelismo e expressões da cultura da dádiva se fazem presentes, também podem ser constatadas.

São essas tramas, alimentadas por uma assimetria de informações sobretudo no caso da cana -, que nos levam a reconceituar a "parceria", 
diferenciando-a dos termos em que ela aparece na legislação específica (Estatuto da Terra, art. 96 e incisos). Como esclarecimento inicial, cabe-nos afirmar que a concepção de parcerias e de parceiros analisados na relação dos assentamentos com as agroindústrias produz uma situação bastante diversa da prevista pelo Estatuto da Terra (Lei no 4504/64) e seu regulamento (Decreto no 59566/66). ${ }^{8}$ Esta diversidade na questão dos direitos e obrigações, na partilha dos riscos e de outras tantas questões exige reflexões.

Na situação dos assentados que fornecem cana às usinas, o termo "parceria" aparece referido a uma portaria da Fundação Instituto de Terras do Estado de São Paulo "José Gomes da Silva" - Itesp (Portaria Itesp no 75 de 24/10/2002, alterada pela Portaria no 77 de 27/07/2004). Trata-se, portanto, de um termo utilizado pelos órgãos gestores para definir a política de desenvolvimento dos assentamentos rurais. Entre os programas que poderiam proporcionar o desenvolvimento sustentável das comunidades assentadas, aparece a referência à formação de "parcerias negociais" Igrifo nosso] visando alocar recursos e dinamizar o processo de capitalização das famílias beneficiárias dos projetos de assentamento, objetivando sua autonomia, sustentabilidade, maior participação na economia dos municípios e suprimento de matéria - prima para as agroindústrias.

Estas expectativas vão se confrontar com a situação concreta da parceria com os assentados, expressão institucional de um contrato no qual são detectadas relações assimétricas de poder. São as desigualdades constitutivas dessa relação responsáveis pela controversa integração dos assentados às parcerias com as usinas de açúcar e álcool. Estamos bem longe, também, da situação clássica de "parceria", descrita por Antonio Candido (1987). Em Os parceiros do Rio Bonito encontramos o que po-

8 Anteriormente, o Código Civil de 1916, especificamente nas modalidades agrícola e pecuária, fazia referência à parceria rural, deixando de fazê-lo somente em 2002, com a promulgação do novo Código Civil. 
deríamos chamar de uma forma de arrendamento em espécie, unindo proprietários e parceiros num universo social no qual as distâncias sociais e as distorções na gestão do negócio são pequenas. Nos assentamentos, está em questão uma forma de arrendamento totalmente mercantil, que se tenta disfarçar de variadas maneiras, às vezes com algum regramento oficial na transação (no caso dos canaviais implantados segundo Portaria do Itesp). Além disso, inverte-se a relação: no estudo clássico, os fazendeiros cediam parte de suas terras para lavradores mediante recebimento de parte da colheita; na atualidade, os assentados é que cedem parcela de seus lotes para que as usinas plantem a cana.

Espreitando efetivamente uma desigualdade de condições, a parceria tem se desconfigurado pelas práticas adotadas. Nessa reconstrução sociológica, a "parceria" com as agroindústrias, nos termos em que ela vem se concretizando, exige a sua desconexão da matriz conceitual de "capital social", que tem, como princípio, parcerias sociais embasadas em valores como solidariedade, reciprocidade, cooperação e confiança (Putnam, 2000). As sucessivas quebras e burlas de pactos rompem com a confiança que deveria, em princípio, embasar a parceria - redundando em mudanças significativas nos termos previstos nos contratos. Mudanças que implicam, muitas vezes, restrições concretas à conquista de autonomia.

\section{A parceria no cenário dos assentamentos}

O vai e vem da entrada da cana nos assentamentos rurais na região de Araraquara

Há mais de quinze anos, a proposta de um "consórcio" para produção de cana agroindustrial no assentamento Monte Alegre envolveu a Prefeitura de Motuca, uma usina localizada no município e órgãos do Estado, gerando desdobramentos e divisores de águas, pondo em discussão 
o modo de vida constituído nos assentamentos, a perspectiva da agroindústria conviver com espaços diversificados de produção/reprodução social e, especialmente, o significado da cana como possível estratégia de permanência na terra. A trajetória produtiva dos agricultores assentados nessa região oscilou, desde meados da década de 1980, entre a produção de grãos nos anos iniciais, uma busca por diversificação agrícola que vai da fruticultura a algumas experiências isoladas de produção orgânica, chegando a esta mal-resolvida (política e juridicamente) integração ao complexo agroindustrial sucroalcooleiro.

A polêmica adesão dos assentados ao cultivo agroindustrial da canade-açúcar acaba por ser o mais evidente e, ao mesmo tempo, contraditório exemplo do jogo de resistências e acomodações que permeia a trajetória dos assentamentos. O "consórcio" - antecedente da parceria - anunciado como a única perspectiva de viabilizar economicamente os assentamentos de trabalhadores rurais baseava-se, na verdade, no atributo de ser o boiafria incapaz de "tocar a terra". A omissão do Estado não era discutida. A plantação de cana, à semelhança de um arrendamento, permitiria, sob os termos então anunciados, um aumento do poder aquisitivo do assentado. Dos dezesseis hectares de terra de cada assentado, doze seriam utilizados para plantação de cana-de-açúcar. Nos quatro hectares remanescentes, o assentado poderia plantar o que quisesse, dependendo de sua livre decisão. A usina acrescentava a isso uma série de benefícios, como a contratação de um membro da família assentada, ração para gado e leite de soja.

O exame das peças constitutivas desta proposta de consórcio nos põe diante de um quadro no qual a liberdade e a autonomia dos agricultores são perdidas, sendo recriada uma típica forma de dependência frente à Usina. Poderes e controles a esquadrinhar o novo espaço social, reenquadrando-o nas marcas do "trabalho cativo". 
Em meados de 1995, a usina reaparece nos núcleos da Fazenda Monte Alegre com uma proposta de consórcio modificada, estipulando $50 \%$ da área dos lotes para o plantio de cana-de-açúcar, sendo retirados todos os benefícios diretos e indiretos presentes no modelo anterior. A contraproposta formulada pelo Sindicato dos Empregados Rurais (mediador dos assentados), que previa a cooperativização para a produção da cana, frustrou-se pelas próprias dificuldades associativas e pela resistência à adaptação a modelos coletivos forjados por outros para suas vidas.

Desde então, a pressão que as usinas exercem sobre os projetos de assentamentos a fim de que se dediquem à produção canavieira, passando a ser fornecedores de matéria-prima para as agroindústrias, nunca se interrompeu efetivamente. De forma mais ou menos dissimulada, a proximidade e o cercamento das usinas se constituiu, nos últimos anos, em uma sombra a nublar a perspectiva de uma produção pluralista e diversificada nos assentamentos da região.

Após anos de debates e polêmica, o ITESP, através de portarias (75, de 2002, modificada pela 77, de 2004), estabeleceu parcerias entre lotes agrícolas dos assentados e agroindústrias, sob o argumento de dinamização do processo de capitalização das famílias beneficiárias dos projetos de assentamentos. Justificou a portaria que acabou por consentir, sob regras, o plantio da cana, como perspectiva de garantir maior participação dos assentados na economia dos municípios.

Foi mantido o limite de $50 \%$ da área total nos lotes com área até quinze hectares, nos lotes com área superior a quinze hectares, estipulouse até $30 \%$ da área total. A determinação foi de que a exploração deveria ser feita de forma individual, associativa ou coletiva, ficando proibida outra modalidade de exploração que não permitisse a participação direta dos beneficiários no planejamento, na condução e na comercialização da produção. Tais determinações contrastam com o que passou a ocorrer. 
O Itesp, de fato, nunca controlou tais limites. Há manifestações de resistência, agravadas no caso das queimadas que passam a entrar, sem pedir licença, nas casas e nos lotes dos assentados.

O movimento sindical, a princípio afastado desta disputa, voltou a entrar em cena, estimulando audiências públicas e manifestações de resistência por parte dos assentados. Apesar das afirmações de que prefeitura e órgãos técnicos têm todos os critérios para evitar que os assentamentos sejam arrendados ou danifiquem o ambiente, a realidade começou a mostrar outras facetas, que explodiram principalmente nas questões das queimadas e da quebra da autonomia, prevista em princípio no acordo sobre o plantio da cana.

No outro espaço estudado em Araraquara, no assentamento Bela Vista do Chibarro, sob jurisdição do INCRA, há denúncias de que os assentados começaram a arrendar suas terras desde o início dos anos 2000. O INCRA manteve-se, em tese, contrário ao plantio de cana, embora sua omissão fosse patente durante anos a fio. A polêmica com relação à cana foi um dos vetores de articulação de um novo grupo, formalizado na Associação Independente, uma interessante entidade através da qual os assentados prócana se mobilizaram no espaço político interno do assentamento (inclusive ganhando postos de coordenação do mesmo) e se fizeram representar externamente. Esses agricultores, frustrados pela crise do cultivo de grãos (a mesma que assolou a Monte Alegre alguns anos após sua instalação), foram atraídos pela possibilidade de explorar o cultivo da cana-de-açúcar numa espécie de arrendamento via Associação. Sem controle oficial, vivenciando o descompasso entre INCRA (planejador e implantador do PA) e ITESP (gestor da assistência técnica no PA), a implantação da cultura da cana-deaçúcar em larga escala no PA Bela Vista terá lugar nos anos 2000/2001, quase sempre mediante a atuação da Associação Independente.

O INCRA tem procurado, nos últimos anos, retomar seu papel gestor de fato. Isto se expressou concretamente na instalação de um escritó- 
rio do órgão em Araraquara (em 2005), que acabou por solicitar a reintegração de posse nos lotes irregulares ou totalmente arrendados às usinas. Esta situação tem acirrado os conflitos e parece se sobrepor a qualquer perspectiva de cooperação. A posição do INCRA tem sido, na atualidade, frontalmente contrária ao plantio de cana. Iniciativas, ainda que tímidas, de outras alternativas de produção/reprodução social vêm sendo propostas pelo INCRA, que tem buscado, na parceria com o movimento sindical e com a Prefeitura Municipal de Araraquara, construir outro caminho para o assentamento Bela Vista do Chibarro. Construção que tem enfrentado conflitos e cisões.

Após um conflituoso despejo judicial ocorrido recentemente (dezembro/2007), busca-se orquestrar um movimento de abandono das parcerias não legais com as usinas neste assentamento. Assim, em meados de 2008, cinquenta assentados da Bela Vista solicitaram a ruptura de contrato com a Usina Zanin (principal compradora/plantadora de cana no assentamento), com a erradicação da cana-de-açúcar existente em seus lotes. Organizados pelo Sindicato dos Empregados Rurais e apoiados pelo INCRA, esses assentados estão negociando, atualmente, os termos dessa rescisão contratual.

O movimento que vem sendo observado de rompimento das parceiras pode ser visto, por um ângulo, como uma tentativa de reapropriação do espaço dos assentamentos pelos assentados. Pode ser, por outro lado, uma reação acomodatícia, provocada pelo receio de sofrerem ações de reintegração de posse por parte do órgão gestor, semelhantes às sofridas por um grupo de famílias em dezembro de 2007. O futuro dessa iniciativa ainda é incerto, posto que bastante recente. No entanto, o movimento parece caminhar aceleradamente com a aparente concordância das usinas, situação que, como reiteramos, merece ser avaliada cuidadosamente.

A polêmica da cana nesse assentamento pode ser vista como um exemplo paradoxal da resistência dos assentados frente às imposições estatais e dos mediadores externos, mesmo que tenha significado - simulta- 
neamente - um movimento de acomodação dessa população em relação às forças econômicas regionais.

Nas terras de Teodoro Sampaio, a cana pede passagem

A primeira iniciativa de produção de cana para fornecimento agroindustrial nos assentamentos do Pontal do Paranapanema teve início em 1993, no assentamento Água Sumida em Teodoro Sampaio. Apesar de constar, em relatório oficial da época, que se tratava de um projetopiloto para apenas onze produtores (9\% de 121 assentados), esse mesmo documento dá conta que 27 beneficiários teriam interesse em implantar a cana. ${ }^{9}$ A mobilização, puramente institucional, em torno dessa questão resultou em uma permissão oficial para o grupo de onze e uma outra, oficiosa, para todos os demais interessados. Registra-se que os documentos do INCRA, do ITESP e da Unesp - que emitiu um parecer técnico, a pedido do ITESP, em 1995 - foram todos inconclusivos, no geral assumindo uma postura ambígua entre a condenação à produção para a agroindústria sucroalcooleira e o reconhecimento da expectativa de segurança econômica dos assentados envolvidos.

Como agente privilegiado nesse processo, encontra-se a Destilaria Alcídia, também localizada em Teodoro Sampaio. Além de promotora do projeto "especial" no P.A. Água Sumida, a Alcídia continuará sendo, ao longo de anos a fio, a principal empresa processadora da cana fornecida pelos assentados da região. Uma análise da documentação produzida na década de 1990 já revela que, além da utilização das terras, a usina também foi beneficiada, indiretamente, com os recursos financeiros dirigidos aos assentados (créditos subsidiados, específicos para a agricultura fami-

9 Cf. Sobre a proposta da Destilaria Alcídia a respeito da implantação a cultura da cana nos assentamentos do Pontal do Paranapanema. Secretaria da Justiça e Defesa da Cidadania/Instituto de Terras/Departamento de Assentamento Fundiário, São Paulo, s.d. (p. 02). 
liar). Nos anos 2000, a Alcídia estará novamente envolvida em projetos com assentados, sempre contando com o financiamento do PRONAF.

Enquanto na região de Araraquara a tentativa de implantação da cana com destinação agroindustrial sempre foi envolvida em forte polêmica, tendo o movimento sindical rural como antagonista das diferentes propostas para que assentados destinem suas terras à cana, no Pontal, o principal núcleo articulador político dos assentados (o MST) não detinha forte presença nos assentamentos nos quais a Destilaria Alcídia buscou plantar cana e pouco fez, concretamente, para confrontar essa ação. Essa falta de contrapressão política explica, ao menos em parte, a facilidade com que a empresa atuou junto aos assentados e técnicos oficiais. No caso do Água Sumida, o MST sequer havia se organizado na região quando da implantação do assentamento (final dos anos 1980). Distantes geografica e politicamente da movimentação em Araraquara, os assentados do P.A. Água Sumida tiveram condições de experimentar uma "parceria" fácil com o setor sucroalcooleiro.

Além das facilidades institucionais e políticas, muitos foram favorecidos pelo fato de que este assentamento conta com lotes de três diferentes dimensões, variando entre 16,8 e 36 hectares. Segundo Botasim (2002), a possibilidade de exploração mista (cana e pecuária leiteira) nos lotes médios e grandes teria sido um fator importante para o incremento econômico das famílias assentadas. No entanto, Ramos (2005), que também estudou o caso da cana no Água Sumida, constata que a renda dos que plantaram cana em "parceria" com a Alcídia variou em função da qualidade do solo algo também citado por Botasim (2002) - mas, principalmente, pela maior ou menor dedicação (por parte dos próprios assentados) nos tratos culturais, principalmente na não aplicação das quantidades recomendadas de adubo, fator limitante da produtividade nos últimos cortes.

A partir de um declínio na renda obtida na cana entre 1999 e 2000, os assentados deste P.A. foram levados a não renovar os plantios. Essa ex- 
periência de integração ao complexo agroindustrial da cana foi encerrada por volta de 2002. Ramos (2005), que entrevistou os assentados que plantaram cana, cita que estes não rechaçam totalmente a experiência, considerando que ela foi financeiramente vantajosa por algum tempo e que, se fossem repetir essa cultura, buscariam maior controle no contrato e nos mecanismos de avaliação da cana colhida. Nota-se, nessa experiência, uma possibilidade de obtenção de renda que, no correr de poucos anos, se frustra. O abandono da cultura da cana, no entanto, não causou significativos prejuízos para os assentados, ao menos, isso não foi detectado em suas falas.

Se o cultivo da cana agroindustrial acabou no PA Água Sumida, a trajetória dessa cultura nos assentamentos da região, sempre patrocinada pela já conhecida Destilaria Alcídia, continuou nos anos subsequentes. Mais recentemente, assentados dos PAs Santa Terezinha da Alcídia e Alcídia da Gata, vizinhos da área industrial da Alcídia, implantaram a cultura da cana para fornecimento a essa usina. Desta feita, se a empresa processadora é a mesma, as condições de fornecimento da polêmica planta variam.

Em primeiro lugar, se os canaviais do assentamento Água Sumida foram permitidos, no mais, oficiosamente pelo INCRA (o assentamento é de responsabilidade federal), no caso dos dois mais recentes assentamentos que plantaram cana, essa nova cultura foi implantada mediante uma portaria oficial da Fundação ITESP (a mesma Portaria 75/2002, que regulamenta a exploração sucroalcooleira nos assentamentos de Motuca e Araraquara), que busca - ao menos em tese - estabelecer normas para o plantio de culturas destinadas à venda para agroindústrias nos projetos de assentamentos estaduais. A partir dos critérios estipulados pela Portaria 075/2002, os P.A.s Alcídia da Gata e Santa Terezinha da Alcídia, com 18 e 26 lotes de 20 hectares. respectivamente, entraram nesse circuito.

A luta pela terra nessa área, encetada por ex-arrendatários e boiasfrias (inclusive ex-funcionários da Alcídia), teve origem no início dos anos 1990, tendo sido encampada pelo Movimento dos Agricultores Sem-Terra $(\mathrm{MAST})^{10}$ anos mais tarde. Depois do assentamento do primeiro grupo na 
fazenda Alcídia da Gata, um segundo grupo, do mesmo acampamento, foi assentado na fazenda Santa Terezinha da Alcídia, que estava arrendada para a Destilaria Alcídia para cultivo de cana.

Assim como no caso do PA Água Limpa, não houve uma maior discussão, nem pressões por parte de alguma organização de trabalhadores, sobre os impactos ou o sentido dessa "parceria" da cana. Novamente, observa-se que os assentamentos que aderiram a contratos para cultivo de cana-de-açúcar não estão na órbita do MST, principal polo político dos trabalhadores sem-terra e assentados na região. Além disso, a proximidade geográfica da usina (maior ainda que o PA Água Limpa) só fortalece o poder de influência da empresa. No caso do PA Santa Terezinha da Alcídia, no entanto, o fato da área estar arrendada pela Alcídia serviu, também, para uma "negociação" entre a empresa, os trabalhadores e o ITESP, desde a implantação do PA. ${ }^{11}$

A formalização da parceria com a usina para plantio de cana nesses assentamentos foi totalmente mediada pelo ITESP, em tese, seguindo as recomendações da portaria oficial. Isso se comprova pela área dos lotes destinada para a cana, que seguiu à risca a determinação de 30\% da área total dos lotes, quando estes forem de dimensão superior a quinze hectares. No entanto, novamente verifica-se, desta feita através da documentação recolhida na pesquisa de campo ${ }^{12}$, que a implantação da cultura da cana para fornecimento à Destilaria Alcídia, tanto no PA Alcídia da Gata, quanto no Santa Terezinha da Alcídia, foi totalmente financiada pelo Pronaf. Além de aproveitar-se de uma brecha de interpretação na Portaria 075 do ITESP - que afirma, no parágrafo quinto do seu artigo segundo,

10 Sobre a origem e a ação do MAST, cf. LIMA, E. C. Os movimentos sociais de luta pela terra e pela reforma agrária no Pontal do Paranapanema (SP): dissidências e dinâmica territorial. Dissertação de Mestrado em Geografia. Presidente Prudente, FCT/Unesp, 2006.

11 Cf. Leal (2003), a Destilaria Alcídia teria garantido benfeitorias (roda-d'água, estradas, materiais de construção) aos assentados, quando da implantação do PA.

12 Agradecemos especialmente a Antonio Carlos Ferreira Júnior, cuja pesquisa de Iniciação Científica, realizada nos anos de 2005-2006, forneceu dados para esta discussão. 
que as áreas dos lotes comprometidas com projetos agropecuários financiados pelo Sistema Nacional de Crédito Rural, ou com programas oficiais de fomento, não poderão ter implantadas culturas para fins de processamento industrial -, esse financiamento contraria o "espírito da lei", ao menos a partir do que foi declarado à pesquisa por um dos redatores da portaria, para quem "ela foi feita para que as usinas não se aproveitem do financiamento subsidiado dos assentados", algo que julgava um "abuso". ${ }^{13}$

Se toda negociação entre assentados e usina foi mediada pelo ITESP, que inclusive produziu o contrato e o projeto técnico, os assentados denunciam que a prometida presença fiscalizadora do ITESP sobre a execução da "parceria" está aquém do devido. "Colocaram a cana e sumiram", disse um dos assentados que aderiram à parceria. Outro, sobre a possibilidade de renovação do contrato para um outro período de cultivo da cana, afirmou: "Cana? Só pra usina roubar. E o ITESP rouba junto com a usina". Embora não confirmada, também foi ventilada a denúncia de que os técnicos do ITESP do escritório de Teodoro Sampaio (autores dos projetos técnicos para a parceria) estariam prestando serviço para a Destilaria Alcídia através de uma empresa particular de assessoria técnica.

Para além desse verdadeiro imbróglio administrativo, o resultado financeiro da execução dos projetos de cultivo da cana-de-açúcar para fornecimento à Destilaria Alcídia teve, como no caso dos contratos firmados no P.A. Monte Alegre (região de Araraquara), uma visível disparidade entre a renda prevista e a realizada. No assentamento Alcídia da Gata, treze dos dezoito assentados aderiram ao "consórcio" com a usina e tiveram resultados aquém do previsto no projeto financeiro apresentado ao Banco do Brasil para tomada de crédito: "Foi tudo para o banco", disse um dos produtores.

No caso do P.A. Santa Terezinha, que tem lotes distando até menos de 500 metros da área industrial da Destilaria, 24 dos 26 assentados plantaram

13 Declaração feita em 2004 por um ex-diretor do ITESP, hoje funcionário do INCRA. 
cana. A maioria deles também teve dificuldade em saldar o financiamento do Pronaf, tomado para plantar a cana. Os resultados diversos, segundo levantamento realizado por Ferreira Júnior (2007), apresentam apenas dois assentados auferindo renda líquida dentro do previsto. A expectativa dos assentados estava - ainda segundo o autor acima citado - na renda a ser recebida no último ano do contrato, quando não haveria desconto do financiamento. No entanto, boa parte dos assentados apenas cobriria os prejuízos dos anos anteriores, nos quais a renda paga pela Destilaria, muitas vezes, mal cobriu os compromissos dos assentados com o banco.

Se não foi registrada uma mobilização política que, ao contestar essas parcerias, estivesse criando mecanismos concretos de acompanhamento e negociação permanente nos termos não explícitos no contrato - como a assistência e fiscalização do ITESP, ou o controle do cálculo do $\mathrm{ATR}^{14}$-, estranha-se, que, numa possível avaliação, em nenhum momento, foi questionada a utilização de recursos do PRONAF para o cultivo agroindustrial da cana nesses assentamentos. Essa "parceria" possibilitou que a empresa processadora de cana implantasse a cana nessas áreas a "custo zero", pois todas as operações realizadas pela usina foram pagas pelos assentados com o financiamento.

Essa paradoxal condição - ainda mais flagrante porque contextualizada na região onde mais os trabalhadores sem-terra se mobilizam - só tende a se agravar, na medida em que se verifica o aumento da área plantada de cana na região. No contexto de expansão recente da produção sucroalcooleira no Oeste Paulista (abrangendo a região do Pontal do Paranapanema), uma nova destilaria, localizada no município de Mirante do Paranapanema (o de maior número de famílias assentadas do Estado), já teve sua área ocupada pelo MST - numa jornada realizada em ju-

14 "Açúcar Total Recuperável" (ATR), índice computado para cada partida de cana, no momento do corte, sobre o qual calcula-se o valor a ser pago pela tonelada de matéria-prima colhida 
nho/2008. No entanto, o aumento da área plantada de cana na região é patente, e a nova unidade industrial (também propriedade da Odebrecht) - chamada "Usina Conquista do Pontal" - será uma incômoda vizinha para outros assentamentos.

O circuito de paradoxos das parcerias: riscos de arrendamentos e recriação de laços clientelistas

O que têm significado, efetivamente, os contratos feitos pelos assentados em parceira com empresas ou agroindústrias? Existem diferenças marcantes entre as diversas parcerias com o setor privado. Não é incomum, embora de difícil avaliação quantitativa, que assentados negociem parcela de seus lotes para cultivos agroindustriais voltados para a produção de alimentos, sendo o caso da mandioca o mais recorrente. A utilização maior ou menor da mão de obra familiar dá a tônica nesta diferenciação. Mesmo nas "parcerias" com as usinas, está prevista - a partir das Portarias do Itesp - a utilização da força de trabalho do assentado em determinadas tarefas do ciclo produtivo. As variações nos mercados específicos de cada produto também são importantes fontes de análise pois, mesmo com contratos assinados, as oscilações dos preços no momento das vendas dão grandes diferenciais na hora de receber pelos produtos. Isto pôde ser constatado nas duas regiões que foram objeto de análise.

No caso da cana-de-açúcar agroindustrial, encontramos o exemplo mais complexo de parcerias entre assentados e setor privado. As usinas têm um longo histórico de assédio aos pequenos produtores assentados para o plantio nos lotes, conforme expresso na produção acadêmica voltada a esta temática (Stetter, 2000; Baú, 2002; Ferreira Júnior, 2007).

Verificamos outros impactos e consequências da atuação do setor canavieiro, principalmente no que se refere às questões ambientais e sociais afetadas pelo processo produtivo de álcool e açúcar. Dentro da 
parceria com os assentados, plantar a cana implica problemas, como a fragmentação interna nos assentamentos entre os que plantam ou não, incluindo-se brigas e violência física. Além de trazer um forte risco de arrendamento da terra, inúmeros problemas relacionados às queimadas e aos demais métodos produtivos têm afetado diretamente a população assentada em seu espaço de moradia e de trabalho.

A diferença de posição que os órgãos gestores (Incra e Itesp) adotaram aprofunda as contradições e ambiguidades dessa realidade. Tais diferenças entre as posições dos órgãos têm demarcado o campo político no contexto da gestão dos projetos de assentamentos no Estado de São Paulo, com acusações mútuas de omissão frente ao dilema do desenvolvimento econômico e social desses territórios. Nossa prioridade de análise, no entanto, é a discussão das controvérsias e das armadilhas, muitas vezes dissimuladas, que se apresentam nas sedutoras parcerias propostas pelas usinas aos assentamentos rurais.

Com a publicação da Portaria que permite o plantio de cana por parte do Itesp, ocorreu uma explosão de contratos para o plantio de cana agroindustrial no assentamento Monte Alegre. Desde então, o número de assentados que tem aderido à parceria vem aumentando rapidamente. Os serviços de formação do canavial são disponibilizados apenas na primeira safra (de dezoito meses) e descontados em tonelagem, 50\% na primeira colheita, $30 \%$ na segunda e $20 \%$ na terceira, embora nessas duas últimas e demais safras os assentados já não puderam contar com esses serviços feitos pela usina. Eles tiveram que financiar os custos da produção com o dinheiro ganho nas safras anteriores sem o apoio que receberam da usina na primeira, a chamada "produção facilitada".

Apenas o trato e o corte seriam responsabilidades das famílias. O corte, na verdade, seria feito por mutirões, de forma que cada assentado participaria no corte dos demais. No entanto, não houve organização 
para isso, e o que ocorreu foi a terceirização da mão de obra por turmas da usina. Este é um dos fatos, denunciados pelo grupo contrário à cana, que caracterizariam a "parceria" como arrendamento: em muitos lotes não há trabalho familiar nos canaviais. Mesmo o trato diário foi feito muitas vezes por terceiros, ou seja, o financiamento, a preparação da terra, o plantio, a colheita, o transporte e a pesagem ficaram a cargo da usina.

Vimos então, antes mesmo da primeira colheita, que os assentados ficam à mercê do que a usina quer fazer nos lotes. As desconfianças de alguns assentados com essa parceria foram se manifestando, especialmente em vista dos gastos com insumos, adubos e pagamento de mão de obra.

Ao contrário do que falavam os técnicos da usina e do Itesp, e mesmo alguns assentados empolgados com a cana, a renda conquistada fica, em muitos dos casos, abaixo do esperado. Além disso, os assentados ficam com metade da área de seus lotes presa num contrato de cinco anos - tempo superior ao previsto no Estatuto da Terra - e inutilizada para outras culturas se quiserem abandonar a cana. Tal perda de liberdade sobre suas terras já é traduzida hoje pela intenção de abandonar as "parcerias" ou até por processos judiciais para anular o contrato e sair da parceria, processos complexos, de resultados não imediatos.

Há outros elementos a considerar nesta trama, entre eles, a relação de compadrio que alguns assentados têm com usineiros, o que por vezes os beneficia na hora de "pegar o cheque". Durante uma mesma safra, o lucro de assentados que plantaram no mesmo período, no mesmo volume de área, varia muito. Existem assentados que parecem ser um tipo de representante da usina dentro do assentamento: eles controlam as turmas de trabalho que plantam e colhem a cana, as horas de máquinas na preparação da terra. Geralmente alguns deles têm uma antiga relação de trabalho com a usina ou até são funcionários dela. 
Depoimentos de alguns assentados indicam sua desconfiança diante do fato destes terem conseguido alta renda com a cana, enquanto outros estão em endividamento progressivo. Falou-se ainda que, para os assentados do segundo caso, técnicos do Itesp sugeriram que pegassem financiamento do Pronaf para custear a continuação do plantio de cana, o que vem na contramão do princípio desse crédito.

Em Teodoro Sampaio, a experiência que atualmente está em curso (assentamentos Santa Terezinha da Alcídia e Alcídia da Gata) revela uma situação mais preocupante com relação à utilização dos créditos do Pronaf. Lá, conforme descrito acima, toda a implantação e custeio dos tratos culturais são feitos com recursos públicos da agricultura familiar. No entanto, verifica-se, também, a recriação de laços de clientelismo, sobretudo no bom relacionamento que os assentados têm com o setor de assistência social da usina.

Esse bom relacionamento - que, no entanto, comporta também uma crítica à exploração imposta pela usina - viabiliza a manutenção da cultura canavieira e recria uma integração sistêmica, conforme estudado em outros contextos envolvendo pequenos fornecedores de cana (Neves, 1981). Quando a autora estuda o caso dos lavradores da cana no Norte Fluminense, revela que a assistência social - na época regulamentada por norma do extinto IAA - era garantidora da reprodução do sistema de produção da cana, mesmo que esta se mostrasse pouco significativa do ponto de vista financeiro.

O sistema de controles sociais, como um instituto de poder, não deixa de garantir a acumulação capitalista para a agroindústria, muitas vezes beneficiada indireta e indevidamente com o crédito oficial. Favorece também os mediadores no interior do assentamento - aqueles assentados que se põem como agentes das negociações ou de determinadas tarefas no ciclo produtivo. Para além do estritamente econômico, essa configu- 
ração que surge, mesmo que em estágio embrionário, também nos remete ao estudo de Neves (1981). No caso do Assentamento Bela Vista do Chibarro, no qual a introdução da cana se deu de forma não controlada oficialmente, esse "sistema" interno garantiu, a um pequeno número de assentados, uma condição de destaque junto aos companheiros. Assim é que o primeiro presidente da Associação Independente foi lançado como candidato a vereador nas eleições municipais de Araraquara no ano 2000. Figura forte e polêmica no assentamento, seu nome é recorrentemente associado a práticas agressivas. Pesa sobre ele, também, a denúncia de que, no período em que foi presidente da associação, recebia remuneração da entidade (algo em torno de um salário mínimo da época).

Menos exposto, outro assentado também beneficiou-se economicamente com a cana, não apenas como produtor direto. Como um caso bastante paradoxal, esse assentado, cujos parentes assentados sempre se manifestaram contrários à cana, especializou-se no oferecimento de serviços de motomecanização para o cultivo da cana. Assim, teve oportunidade de comprar vários tratores, constituindo-se num serviço terceirizado da usina para preparo do solo no assentamento. As denúncias que recaem sobre esse assentado dão conta de que ele não apenas prestava serviços de trator, mas arrendava terras de outros assentados para aumentar sua produção de cana. Ambos os líderes do grupo pró-cana foram despejados recentemente, na já citada ação de reintegração de posse movida pelo Incra. Os laços sociais, no entanto, têm garantido a eles a manutenção de suas casas no assentamento e certa força na contestação dessa decisão judicial.

Em Teodoro Sampaio, a hegemonia da Destilaria Alcídia sobre o território que a circunda (onde estão instalados os dois assentamentos) é patente. Isso pode ser comprovado pelo fato de que a escola que atende aos filhos dos assentados é a escola da Destilaria, bem como pelo fato de o atendimento de saúde dos moradores dos arredores também ser 
dispensado pelo posto médico da Destilaria. Mais recentemente, corre a informação que a Destilaria Alcídia - hoje de propriedade do grupo Odebrecht - encabeça um movimento no município para a criação do "Distrito da Alcídia".

Nas parcerias, a assimetria de informações é, de fato, constatada, no que diz respeito ao controle da produtividade e da renda auferida com a cana. Apesar disso, há expressões de acomodação. Nesse sentido, constata-se que, nas duas regiões estudadas, a avaliação que os assentados fazem de suas experiências na cana aponta para pontos positivos e negativos. Mesmo na situação de não plantar mais cana, é comum ouvirem-se opiniões de que "se houvesse mais fiscalização do Itesp (em tese, para controlar se os termos dos contratos estão sendo respeitados pelas usinas), a cana seria melhor".

A parceria, em si, se reveste de roupagens enganosas. Os assentados que têm, em princípio, condições novas de reprodução social na terra retornam - via condição de "parceiros associados" - à situação de subordinação vivida anteriormente no passado, enquanto ex-boias-frias explorados pelo trabalho nas usinas.

A cana pode significar um bom dinheiro recebido anualmente, enquanto na outra metade do lote se consegue a manutenção da agricultura familiar, a diversificação agrícola que os provêm de alimento e de renda através da venda do excedente, situação que não pode ser generalizada. Há exemplos, mesmo que restritos, de assentados que produzem hortaliças e legumes, e têm estruturas de horta no lote que lhes garantem o autoconsumo e a renda através da venda direta e da participação em programas municipais. $\mathrm{O}$ dinheiro advindo da horta garante a renda do dia a dia, enquanto o da cana garante uma renda anual para investimento na horta e demais atividades do lote. 
Como dito anteriormente, as variações demográficas da família, a mão de obra disponível e a capacidade de investir em insumos são fatores que mudam de um lote para outro. Os que compram insumos e os aplicam, fazem a carpa, cuidam da cana em seu lote, não podem ser colocados como arrendatários, pois mesmo com todas as características da parceria eles têm trabalho no canavial e fazem um balanço de investimentos e esforços necessários. Por outro lado, existem muitos lotes que são totalmente arrendados, seja pela composição familiar carente de braços ou em função da pluriatividade, sobretudo através do assalariamento fora do assentamento.

Tal situação tem desdobramentos no campo dos direitos trabalhistas e previdenciários. Depoimentos de assentados que recebiam auxílio-doença e que passaram a ter sustados tais direitos revelam que o Sindicato de Empregados Rurais de Araraquara passou a dificultar o fornecimento de declarações da atividade, exigência para o recebimento do beneficio junto à previdência social.

Repensando problemas: o que desponta no horizonte?

Os impactos da expansão da cana não podem ser analisados como um movimento de mão única, como impulsionadores da dinâmica regional ou como geradores únicos de renda à população assentada. A partir do controle do espaço pelos usineiros, a gestão que os assentados puderam imprimir ao território dos assentamentos, nos aspectos de sua mobilização e participação econômica, ficou, em princípio, prejudicada.

Nos contratos firmados com as agroindústrias há uma assimetria de informações. Os assentados desconhecem as fórmulas de previsão da safra, de preço da cana - as quais são de domínio de agentes contratados pelos usineiros -, o que os leva a ficar, de fato, de fora do processo. Os assentados não conseguem saber o valor real de sua produção, o que foi gasto, a quantidade e a qualidade dos insumos, a pesagem da cana e, 
muito menos, como esta produção entra no circuito nacional e internacional de expansão da cana. Tais incertezas estão presentes nas falas dos assentados das duas regiões. Há cláusulas nos contratos que impedem os assentados de qualquer resistência legal aos usineiros, o que cristaliza, efetivamente, uma relação de assimetria.

Nesse quadro, é complicado dizer simplesmente que, ao garantir uma determinada renda, a cana passa a ser responsável pela "eficiência" dos assentamentos ou pela ampliação da renda agrícola e da dinâmica econômica dos municípios. Mesmo porque os assentamentos não podem ser unicamente dimensionados por indicadores de eficiência econômica ou pelas ambiguidades de se avaliar tais experiências pela renda monetária. No acompanhamento dessa difícil travessia em direção à inclusão social e à cidadania, outras questões se apresentam na experiência da reforma agrária.

Na vivência dessa experiência, ao aceitar a parceria da cana, os assentados passaram a enfrentar outros problemas e os riscos de se verem, de fato, em situação "cativa". É preciso igualmente que se diga que não tem havido, no campo das políticas públicas dirigidas a assentamentos, reais oportunidades e/ou alternativas que se contraponham à expansão da cana, com poucas exceções. A própria perspectiva de revitalização da diversificação agrícola acaba sendo afetada, embora não se possa dizer que a mesma saiu de cena, podendo, em princípio, garantir estratégias de permanência na terra, com maior liberdade de decisão familiar.

Nos casos em que os assentados ficam endividados por conta de um contrato, representantes dos órgãos gestores chegam a indicar o financiamento do Pronaf para a continuidade da produção e para que consigam cumprir o contrato. Consequentemente, há uma transferência de renda de financiamentos que serviriam, em principio, para apoiar a agricultura familiar, mas que ficam nas mãos das agroindústrias. 
No Pontal do Paranapanema, os assentamentos vizinhos às usinas fornecem cana mediante projetos do Pronaf, financiando todo processo produtivo da cana, o que aguça as contradições dessa trama de tensões. Ali, é impossível não se considerar criticamente algo que pode ser visto como uma tomada indireta, pela Destilaria Alcídia, de crédito subsidiado para a agricultura familiar. Enquanto a empresa tem todas as suas operações nos assentamentos pagas pelo financiamento, ao assentado resta saldar as dívidas contraídas junto ao banco.

Há outras situações a considerar. Em ambas as regiões estão sendo implantados projetos que visam a estimular a produção de alimentos nos assentamentos (caso das ações fomentadas pelo PAA - Programa de Aquisição de Alimentos, da CONAB). Tais iniciativas devem ser investigadas como um embrião de modelo de desenvolvimento alternativo às economias regionais, reconstituindo uma nova trama, agora composta por outros agentes/agências (além dos assentados, prefeituras e demais mediadores desta política pública).

A expansão da cana provoca certo fascínio, favorecendo, sob um ângulo, a falsa impressão de segurança dos assentados sobre suas próprias vidas. Expectativas pragmáticas que não necessariamente se sustentam ao longo dos contratos de cinco anos. De outro lado, acirram-se conflitos com o órgão gestor, conflitos que estão diretamente ligados à expansão da cana. Esta está, na verdade, no bojo de muitas dessas questões irregulares responsáveis pelo acirramento das divisões que levaram a Bela Vista a ser alvo de manchetes policiais no final do último ano (ocasião do despejo judicial de um grupo plantador de cana).

Parcerias desfeitas, sonhos refeitos?

No presente recentíssimo, cláusulas firmadas entre o Incra, uma das usinas de Araraquara e o Sindicato dos Empregados Rurais local, envolven- 
do cinquenta famílias do projeto de assentamento Bela Vista do Chibarro que solicitaram suspensão de parceria, buscam reparar a situação de assimetria de informações e de posições que tem caracterizado a integração dos assentados aos complexos agroindustriais. Cláusulas estas que, se obedecidas, poderão criar novo cenário em uma das regiões investigadas, pois determinam outro modelo de circulação de informação e fiscalização das operações - basicamente, agora, acompanhados pelo Sindicato local.

Em princípio, a usina ficaria autorizada pelo Incra a realizar todas as operações de colheita da cana-de-açúcar nos lotes do assentamento, tais como aceiros, corte de cana, carregamento e transporte, devendo utilizar seu pessoal e equipamentos respeitando as normas ambientais, trabalhistas e as condições de maturação da cana-de-açúcar. Deve ser frisada a previsão de os custos das operações serem supridos com os rendimentos da própria cana, o que poderá solucionar os problemas das dívidas e pendências que vêm sendo apresentadas aos assentados. No caso em pauta, a usina havia apresentado uma planilha indicando uma dívida de 3 milhões dos assentados, informação que acelerou a decisão das famílias de tentarem sair da parceria.

Registra-se que, ao menos nesta conjuntura (governo Lula), os assentamentos sob responsabilidade do INCRA no Estado não deverão implantar novas "parcerias" com as destilarias para produção de cana em seus territórios. Por outro lado, nada faz prever uma mudança de postura do órgão estadual (ITESP) em relação ao cultivo agroindustrial da cana nos assentamentos sob sua jurisdição.

Nos núcleos da Fazenda Monte Alegre, por exemplo, apesar da resistência à cana se manifestar em algumas famílias, a mediação do ITESP ainda é pautada por ambigüidades - um certo receio pelo futuro se conjuga com as normas da portaria que autoriza o plantio. Ocorreram, no entanto, mudanças. Com a recente falência da Usina Santa Luiza, os as- 
sentados foram divididos em três grupos: os núcleos 1 e 5 têm contratos com a Usina Bonfim, do grupo COSAN, que fica em Guariba; os núcleos 2 e 4 com a Usina São Martinho, que fica em Pradópolis; e os núcleos 3 e 6 com as usinas Santa Cruz (Américo Brasiliense) e Maringá (Araraquara).

A disputa de quatro usinas em torno da produção nos assentamentos da Fazenda Monte Alegre mostra que a parceria com os assentados está longe de ser um negócio ruim, fadado ao fracasso. O envolvimento com as usinas continua a fomentar o drama vivido pelas famílias, ocasionando distorção das perspectivas de cooperação comunitária, imposição de valores competitivos e danos ambientais. Inegavelmente, a expansão da cana põe em questão a gestão do trabalho no interior dos assentamentos. Entretanto, essa mesma presença estimula uma reação daqueles que não plantam cana, na busca por alternativas econômicas e apoio político.

No Pontal do Paranapanema, relações de clientelismo se alternam com situações de proximidade e de distanciamento face ao MST, com as indefinições da Prefeitura, com as estratégias de mobilização buscadas pelos assentados produtores familiares de leite em uma construção de outro modelo de desenvolvimento rural. Lá, também, registra-se uma mobilização em prol da implantação de culturas para a produção de biodiesel, projeto que divide o próprio Movimento dos Sem-terra.

Temos certeza de que nos assentamentos existe uma reinvenção do rural e do local, tanto para as populações assentadas quanto para o entorno. Reinvenção que não elimina a preservação de hábitos culturais próprios de uma cultura camponesa nos mais diferentes espaços da vida social, os quais se expressam através de códigos de reconhecimento social, de elementos da economia moral (Barone, 2000). A expansão dessa modalidade de cultura da cana leva à emergência de novas racionalidades. Por outro lado, as resistências e tentativas de rompimento das parcerias reavivam as perspectivas de diversificação agrícola nos assentamentos. Es- 
tratégias e projetos colocam, frente à frente, as possibilidades da agricultura familiar e o monopólio do agronegócio nos sistemas produtivos e na economia regional.

Aparentemente, a discussão das parcerias dos assentamentos nos põe diante de dois modelos de desenvolvimento, regidos por lógicas diferentes. De um lado, a que, precedida pelo imperativo da integração na racionalidade capitalista, apresenta a entrada da cana nos assentamentos como garantia de autonomia financeira e de permanência na terra. De outro, a que procura levar os agentes políticos locais e regionais a verem na diversificação agrícola e nas alternativas de políticas públicas um outro caminho possível, ainda que cercado de indefinições.

Por outro lado, a perspectiva de serem os assentamentos inseridos na pauta de desenvolvimento local é cercada de muitos paradoxos e do frequente não reconhecimento dos mesmos como vetores estratégicos para a construção de um novo modelo de desenvolvimento.

A implantação de uma política nacional de biodiesel, que define o segmento da agricultura familiar como sua principal base de fornecimento de matéria-prima, projeta impactos ainda não claramente avaliados nos assentamentos rurais, implicando novas estratégias e conflitos no encaminhamento das experiências de reforma agrária. No Estado de São Paulo, a adesão ao projeto de fornecimento de oleaginosas para a produção de biocombustíveis ainda tem um caráter bastante virtual, já que não foi instalada qualquer planta industrial processadora de matéria-prima. No entanto, divergências e concorrências têm marcado a discussão dessa alternativa.

A presença e a expansão da cana nos assentamentos exigem, portanto, uma reavaliação da discussão da sustentabilidade, seja econômica, ambiental ou social, dos assentamentos. A inserção dos assentamentos nos contextos regionais estudados tem se dado mediante tensões explícitas ou latentes, conflituosas ou acomodativas na construção dessa rede de relações, que não tem uma direção unívoca - ela é um construto histórico que tem, na nossa análise, os assentamentos e os atores primeiros desses 
territórios - os assentados - como palco e protagonistas. A mobilização dos assentados e demais agentes que compõem os campos econômico e político nos assentamentos tem gerado distintas soluções no enfrentamento dos dilemas produtivos e da pressão que as agroindústrias exercem para ampliar as terras sob seu controle econômico. Reiteramos, por fim, que cabe a nós, investigadores, analisar alternativas e rumos dessas experiências de Reforma Agrária, os quais não podem ser discutidos sem ser passada em revista, em profundidade, a trama de tensões presentes nos paradoxos da integração do assentamento aos complexos agroindustriais e na difícil, mas possível, perspectiva de um modelo de desenvolvimento alternativo.

\section{Sugarcane partnerships: tensions and contradictions in the development of experiences within rural settlements in the state of São Paulo}

\section{Abstract}

The controversial presence of sugarcane in rural settlements, in the recent years, requires a careful examination of its interference in the way of life of the settlers and in the relationship of the settlements with the dynamics of regional development. The cultivation of sugarcane in the settlements has caused internal conflicts, and put into debate the past, present and future of these experiences. The analysis of the partnership with the agribusiness is entangled in a web of tensions, thus requiring an analytical scrutiny of the inequalities that led to this controversial integration of the settlers into sugar and ethanol processing plants, as well as the socio-economic and environmental consequences of the problematic transformation of rural settlements into sugarcane farms. This article examines the settlements in Araraquara and Pontal do Paranapanema, in the state of São Paulo, and the prospects for another model of development.

Keywords: Rural settlements. Land reform. Expansion of sugarcane. Socio-economic and environmental impacts. 


\section{Referências}

ANTONIO, A. P. O Movimento social e a organização do espaço rural nos assentamentos populacionais dirigidos pelo estado. Os exemplos da alta sorocabana no período 1960-1990. Tese de Doutorado em Geografia. FFLCH-USP, SP, 1990.

BARONE, L. A. Assistência técnica aos assentamentos de reforma agrária: da política reativa ao vazio de projeto - o caso do Estado de São Paulo. Retratos de Assentamentos, ำ 08, Araraquara: FCL/UNESP, 2000.

BARONE, L. A. Conflito e Cooperação: o jogo das racionalidades sociais e o campo político num assentamento de Reforma Agrária. Tese de Doutorado. Programa de Pós-Graduação em Sociologia. FCL. UNESP. Campus de Araraquara, 2002.

BAÚ, C. H. R. Pequenos Produtores fornecedores de cana-de-açúcar na Região de Araraquara (SP): uma estratégia de produção e sobrevivência no assentamento Bela Vista do Chibarro. (Dissertação de Mestrado). Programa de PósGraduação em Sociologia. FCL. UNESP. Campus de Araraquara, 2002.

BOTASIM, R. S. Trabalhador sem-terra assentado: um futuro pequeno capitalista? - estudo do assentamento Água Sumida no município de Teodoro Sampaio/ SP. Monografia de Bacharelado em Geografia. Presidente Prudente, FCT/UNESP, 2002.

BOURDIEU, P. O Poder Simbólico. Rio de Janeiro: Bertrand, 1989.

CÂNDIDO, A. Os parceiros do Rio Bonito. 7ạ ed. São Paulo: Duas Cidades, 1987.

FERNANDES, B. M. MST: formação e territorialização. São Paulo: Hucitec, 1996.

FERRANTE, V.L.S.B. A proletarização não tem cartas marcadas (A terra no horizonte dos bóias-frias). Natureza, História e Cultura - Repensando o Social. Porto Alegre: Editora da Universidade, 1992a.

FERRANTE, V. L. S. B. e BARONE, L.A. Assentamentos Rurais e Desenvolvimento: Tensões, bloqueios e perspectivas texto apresentado no Seminário Internacional sobre Reforma Agrária e Desenvolvimento - FAO/INCRA, Porto Alegre, março/2006.

. Reforma Agrária e Desenvolvimento como liberdade: uma nova visão sobre os assentamentos rurais do Estado de São Paulo - Revista Retratos de Assentamentos. Araraquara, no 10, 2006. 
FERrante, V. L. S. B.; WHITAKer, D. C. A.; BARONE, L. A. Poder Local e Assentamentos Rurais; Expressões de Conflito, de Acomodação e de Resistência. Projeto de Pesquisa (CNPq). Araraquara/Presidente Prudente, Nupedor/ GEPEP, 2003.

FERRANTE, V.L.S.B.; ALY JUNIOR, O. (Orgs.) Assentamentos Rurais: impasses e dilemas (uma trajetória de 20 anos). São Paulo: INCRA/UNIARA, 2005.

FERRANTE, V.L.S.B. A Chama verde dos Canaviais. Tese de Livre Docência. UNESP, Araraquara, 1992.

FERRANTE, V.L.S.B. e BERGAMASCO, S.M.P.P. (Orgs.) Censo de Assentamentos Rurais do estado de São Paulo. Pesquisa Multicamp/UNESP - Análise e Avaliação dos Projetos de Reforma Agrária e Assentamentos do Estado de São Paulo. Dezembro/1995.

FERRANTE, V.L.S.B.; SANTOS, M. P. dos. A Cana nos Assentamentos: novas roupagens, velhas questões. Anais do XLII Congresso da SOBER, Juiz de Fora, julho, 2003. CD Rom.

FERREIRA JÚNIOR, A. C. Ações e políticas públicas para o desenvolvimento dos assentamentos Santa Terezinha da Alcídia e Alcídia da Gata em Teodoro Sampaio/SP. Monografia de Bacharelado em Geografia. Presidente Prudente, FCT/UNESP, 2007.

LEAL, G. M. Impactos socioterritoriais dos assentamentos rurais do município de Teodoro Sampaio/SP. Monografia de Bacharelado em Geografia. Presidente Prudente, FCT/UNESP, 2003.

LEITE, J. F. A ocupação do Pontal do Paranapanema. São Paulo: Hucitec, 1998.

LEITE, S. P. et. al. Impactos dos assentamentos: um estudo sobre o meio rural brasileiro. São Paulo: UNESP, 2004.

LIMA, E. C. Os movimentos sociais de luta pela terra e pela reforma agrária no Pontal do Paranapanema (SP): dissidências e dinâmica territorial. Dissertação de Mestrado em Geografia. Presidente Prudente: FCT/UNESP, 2006.

MARQUES, D. C. Uma Análise Sócio-Jurídica da Parceria Rural em ErváliaMG. Dissertação apresentada à Universidade Federal de Viçosa, Minas GeraisMG, 2007.

MARTINS, J. S. A sociedade vista do abismo - novos estudos sobre exclusão, pobreza e classes sociais. Petrópolis: Vozes, 2002.

MEDEIROS, L.S. de e LEITE, S. (Orgs.) Assentamentos Rurais. Mudança social e dinâmica regional. Rio de Janeiro: Mauad, 2004. 
NEVES, D. P. Assentamentos Rurais - Reforma Agrária em migalhas. Niterói: EDUFF, 1997.

NEVES, D. P. Lavradores e Pequenos produtores de cana. Rio de Janeiro: Zahar, 1981.

PINASSI, M. O.; QUEDA, O. Consórcio Canavieiro: proposta inovadora ou reedição de práticas tradicionais?. Revista de Reforma Agrária, ABRA, № 2, Vol.23, Campinas, maio/agosto, 1993.

PORTARIA ITESP - 75, de 24-10-2002 - Diário Oficial do Estado - Fundação Instituo de Terras do Estado de São Paulo "José Gomes da Silva", 2002.

PUTNAN, R.D. Comunidade e Democracia. A experiência da Itália Moderna. Rio de Janeiro: FGV, 2000.

RAMOS, P. Relatório de contrato de Prestação autônoma de Serviços Técnicos Especializados de Consultoria - Quarto relatório (PROCESSO 15000/2005 CONVÊNIO INCRA - ATES). Campinas, Outubro/2005.

STETTER, E. A. A Cana nos Assentamentos Rurais: presença indigesta ou personagem convidada? (Dissertação de Mestrado). Programa de Pós-graduação em Sociologia, UNESP/Fclar, 2000.

WHITAKER, D.C.A. A Questão da Diversidade em Assentamentos de Reforma Agrária: Araraquara/SP. In: BERGAMASCO, S.M.P.P. et all. Dinâmicas Familiar, Produtiva e Cultural nos Assentamentos Rurais de São Paulo. Araraquara: UNIARA, Campinas: FEAGRI/UNICAMP, São Paulo: INCRA,2003.

Recebido: 01/12/2008

Aceite final: 16/03/2009 